\title{
Research Paper Yield production and economics of different cropping system in south-western part of Punjab
}

See end of the paper for authors' affiliations

Correspondence to :

\section{BALKARAN SINGH} SANDHU

Krishi Vigyan Kendra, SRI MUKTSAR SAHIB (PUNJAB) INDIA

Email: balkaransandhu@ gmail.com

Paper History :

Received : 11.08.2015;

Revised : 15.08.2015;

Accepted : 21.08 .2015
Abstract : A field experiment was conducted during Kharif 2014 and Rabi 2014-15 at Krishi Vigyan Kendra, Sri Muktsar Sahib (Punjab), to find out the best suitable cropping system of the area. The ground water in the area is not fit for irrigation in most of the villages however, the canal water in the district is in sufficient quantity. Twelve cropping systems were evaluated for their production potential and economics. Out of these, seven cotton based and five rice based cropping systems were raised under irrigated condition with recommended package of practices. Among cotton based cropping system, Bt cotton-onion (235.5q/ha) followed by desi cotton-wheat $(123.3 \mathrm{q} / \mathrm{ha})$ gave the higher rice equivalent yield as compared to all other cropping system. Higher rice equivalent yield under Bt cotton-onion cropping system was due to the higher bulb yield and market price of only onion crop and Kharif crop under this cropping system failed to produced any difference among cotton yield from other cotton based cropping system. The lower rice equivalent yield was obtained in Bt cottongobhi sarson (100 q/ha) and Bt cotton-barley (104 q/ha) cropping systems. Among rice based cropping system rice equivalent yield was higher under direct seeded basmati-wheat $(142.2 \mathrm{q} / \mathrm{ha})$ and basmatiwheat $(141.1 \mathrm{q} / \mathrm{ha})$ cropping systems and lower under direct seeded rice-barley cropping system. However, among all cropping system, Bt cotton-onion (Rs. 225373/ha) gave the higher net return followed by direct seeded basmati-wheat (Rs. 143617/ha) and basmati-wheat (Rs. 140105/ha) as compared to all other cropping system. Higher net return under these cropping systems was due to the higher market price of onion and basmati crop during this year.

KEY Words : Cropping system, Cotton, Rice, Rice equivalent yield, Net return

How To Cite This PAPer: Dhaliwal, Nirmaljit Singh and Sandhu, Balkaran Singh (2015). Yield production and economics of different cropping system in south-western part of Punjab. Internat. Res. J. Agric. Eco. \& Stat., 6 (2) : 414-418. 